\title{
Effect of Surfactant on Azithromycin Dihydrate Loaded Stearic Acid Solid Lipid Nanoparticles
}

\section{Azitromisin Yüklü Stearik Asit Katı Lipit Nanopartiküllerde Sürfaktan Etkisi}

\author{
(D) Sayani BHATTACHARYYA*, (D) Priyanka REDDY \\ Krupanidhi College of Pharmacy, Department of Pharmaceutics, Bangalore, India
}

\begin{abstract}
Objectives: Azithromycin dihydrate is a macrolide antibiotic used for the treatment of several types of bacterial infections. The drug shows low oral bioavailability due to its low solubility. In the present work solid lipid nanoparticles of azithromycin dihydrate were formulated, keeping in view enhancement of the solubility and rate of dissolution of the drug.

Materials and Methods: Azithromycin dihydrate loaded stearic acid nanoparticles were formulated by high shear homogenization using three different surfactants, namely Tween 20 , poloxamer 188 , and poloxamer 407 , at a varied lipid surfactant ratio while keeping the quantities of the active ingredient constant. Twelve such formulations were prepared. The nanoparticles obtained were evaluated for drug content, \% drug loading, \% entrapment efficiency, particle size analysis, zeta potential, surface morphology, Fourier transmission infrared spectroscopy, in vitro drug release, and stability.

Results: All the formulations showed good entrapment efficiency and high percentage of in vitro release with a particle size suitable for lymphatic absorption. The nanoparticles formulated with poloxamer 188 showed better characteristics compared to the other surfactants.

Conclusion: This study indicates that stearic acid nanoparticles of azithromycin dihydrate prepared by high shear homogenization can be successively used for improvement of dissolution and thereby oral bioavailability of the drug.
\end{abstract}

Key words: Azithromycin dihydrate, solid lipid nanoparticles, zeta potential, particle size, entrapment efficiency, drug release

öz

Amaç: Azitromisin dihidrat, çeşitli bakteriyel enfeksiyon tiplerinin tedavisinde kullanılan bir makrolid antibiyotiktir. Etkin madde düşük çözünürlüğü nedeniyle düşük oral biyoyararlanım gösterir. Bu çalışmada, etken maddenin çözünürlüğünü ve çözünme hızını arttırmaya yönelik olarak azitromisin dihidratın katı lipit nanopartikülleri formüle edilmiştir.

Gereç ve Yöntemler: Azitromisin dihidrat yüklü stearik asit nanopartikülleri, etken madde miktarını sabit tutarken, farklı lipit yüzey aktif madde oranında üç farklı yüzey aktif madde, Tween 20, Poloksamer 188 ve Poloksamer 407 kullanılarak yüksek hızlı homojenizasyon yöntemi ile formüle edilmiştir. Bu yöntemle on iki formülasyon hazırlanmıştır. Elde edilen nanopartiküller etken madde içeriği, \% etken madde yükleme, \% enkapsülasyon etkinliği, partikül boyutu analizi, zeta potansiyeli, yüzey morfolojisi, Fourier Transmisyon kızılötesi spektroskopisi, in vitro etken madde salımı, stabilite çalışması için değerlendirilmiştir.

Bulgular: Tüm formülasyonlar, iyi yükleme etkinliği ve lenfatik absorpsiyon için uygun bir partikül büyüklügü ile yüksek oranda in vitro salım göstermiştir. Poloksamer 188 ile formüle edilen nanopartiküller, diğer sürfaktanlara kıyasla daha iyi özellikler göstermiştir.

Sonuç: Bu çalışma, yüksek hızlı homojenizasyon yöntemiyle hazırlanan azitromisin dihidratın stearik asit nanopartiküllerinin, çözünmenin ve dolayısıyla ilacın oral biyoyararlanımının iyileştirilmesi için kullanılabileceğini göstermiştir.

Anahtar kelimeler: Azitromisin dihidrat, katı lipit nanopartiküller, zeta potansiyeli, partikül büyüklüğü, enkapsülasyon verimi, ilaç salımı

*Correspondence: E-mail:sayanibh@gmail.com, Phone: +9845561865 ORCID: orcid.org/0000-0002-4013-4316

Received: 06.06.2018, Accepted: 31.07 .2018

-Turk J Pharm Sci, Published by Galenos Publishing House. 


\section{INTRODUCTION}

In recent years, solid lipid nanoparticles (SLNs) have received a lot of attention in drug delivery systems with the aim to improve solubility and bioavailability and to provide controlled delivery of drugs.' They are submicron colloidal carriers. The particle size varies in a wide range between 50 and $1000 \mathrm{~nm}^{2}$ They are biodegradable and biocompatible, possess low toxicity, and are preferred as potential carriers for a wide variety of poorly soluble drugs. The solid lipid core matrix of SLNs can be used to solubilize lipophilic molecules. They are characterized by their unique properties of smaller size, large surface area, and high drug loading. They have higher potentials than polymeric nanoparticles, fat emulsions, micelles, and liposomes. The suitability of SLNs as carriers is seen in the improvement of biopharmaceutical parameters of poorly soluble drugs, mainly enhancement of bioavailability, drug stability, drug targeting and thereby minimizing toxicity. From the manufacturing point of view they offer limited or no use of organic solvents and ease of scale up for large-scale production. ${ }^{3-5}$

Azithromycin dihydrate (AZT) is a new generation macrolide antibiotic. It is an azalide with a 15-membered azalactone ring. It is derived from erythromycin and possesses enhanced antimicrobial activity. It is prescribed for once daily dosing because of its long half-life. According to the Biopharmaceutical Classification System, AZT can be classified as a class II drug; therefore, the rate-limiting step in the process of drug absorption is the dissolution of the drug, which accounts for its low bioavailability. ${ }^{6,7}$ Furthermore, it is a substrate of the p-glycoprotein transport system, which is further responsible for its low bioavailability due to ileal clearance (biliary plus intestinal excretion clearance). ${ }^{8,9}$

Therefore, the present investigation aimed to prepare and characterize azithromycin loaded SLNs using stearic acid with different surfactant combinations with a view to improve the solubility of AZT. It can be used as an alternative carrier transport system to improve the dissolution and bioavailability of AZT.

\section{MATERIALS AND METHODS}

\section{Materials}

AZT was a gift sample from Strides Ltd, Bangalore. Stearic acid was procured from Loba Chemicals Pvt. Ltd, Mumbai, India. Tween 20 was procured from SD Fine Chem Ltd. Poloxamer 188 and poloxamer 407 were obtained from Dr. Reddy's Laboratories. All other reagents and solvent used were of analytical grade.

\section{Methods}

Preparation of AZT SLNPs by high shear homogenization The SLNs of AZT were prepared using stearic acid and different surfactants in varied proportions by high shear homogenization. $^{10}$ Table 1 reports the composition of AZT loaded SLNs. The selected lipid and the different surfactants were varied in ratio from 1:1 to 2:1. Melting of stearic acid was carried out above its melting point. The drug was dispersed in the molten lipid. A solution of surfactant in distilled water at the same temperature of the molten drug lipid mixture was added to the drug lipid mixture and emulsified by a high shear homogenizer (Polytron PT 1600E Kinematica AG, Switzerland) at 25,000 rpm for $20 \mathrm{~min}$. The nanoemulsion thus formed was subjected to cooling at room temperature. Azithromycin loaded SLNs were finally obtained and stored in a desiccator for further evaluation.

\section{Evaluation of solid lipid nanoparticles}

\section{Drug content}

For determining drug content, $250 \mathrm{mg}$ of SLN was weighed accurately and dissolved in phosphate buffer $\mathrm{pH} 6.0$ up to $250 \mathrm{~mL}$. Then $1 \mathrm{~mL}$ was taken and diluted to $100 \mathrm{~mL}$ with phosphate buffer $\mathrm{pH} 6.0$ and the solution was analyzed spectrophotometrically at $482 \mathrm{~nm}$ using $13.5 \mathrm{~mol} / \mathrm{L}$ sulfuric acid as color developing agent. Percentage drug content was calculated using the formula; ${ }^{11}$

$\%$ Drug content $=\frac{\text { Absorbance of test }}{\begin{array}{c}\text { Absorbance of standard } \\ \text { at the same dilution }\end{array}} \times 100$

\section{Determination of entrapment efficiency and drug loading}

The entrapment efficiency was determined by centrifugation. SLN dispersion equivalent to $10 \mathrm{mg}$ drug was centrifuged at 15,000 rpm for 60 min using a Remi cooling centrifuge (Mumbai, India). The supernatant layer was diluted with phosphate buffer $\mathrm{pH} 6.0$ and the absorbance was measured at $482 \mathrm{~nm}$ in a ultraviolet visible spectrophotometer (Shimadzu 1800, Japan) using $13.5 \mathrm{~mol} / \mathrm{L}$ sulfuric acid as color developing agent.12 The

\begin{tabular}{|c|c|c|c|c|}
\hline \multirow{2}{*}{$\begin{array}{l}\text { Formulation } \\
\text { code }\end{array}$} & \multicolumn{4}{|c|}{ AZT -SLN dispersion $(\% \mathrm{w} / \mathrm{w})^{*}$} \\
\hline & $\begin{array}{l}\text { Stearic } \\
\text { acid }\end{array}$ & $\begin{array}{l}\text { Tween } \\
20\end{array}$ & Poloxamer 188 & Poloxamer 407 \\
\hline F1 & 2 & 1 & - & - \\
\hline F2 & 2 & 2 & - & - \\
\hline F3 & 2 & 3 & - & - \\
\hline F4 & 3 & 2 & - & - \\
\hline F5 & 2 & - & 1 & - \\
\hline F6 & 2 & - & 2 & - \\
\hline F7 & 2 & - & 3 & - \\
\hline F8 & 3 & - & 2 & - \\
\hline F9 & 2 & - & - & 1 \\
\hline F10 & 2 & - & - & 2 \\
\hline F11 & 2 & - & - & 3 \\
\hline $\mathrm{F} 12$ & 3 & - & - & 2 \\
\hline
\end{tabular}

For each formulation azithromycin dihydrate concentration is $1 \% \mathrm{w} / \mathrm{w}$. AZT: Azithromycin dihydrate, SLN: Solid lipid nanoparticles 
percentage entrapment efficiency and percentage drug loading were calculated from the following equations: $:^{13,14}$

$\%$ Entrapment efficiency $=\frac{\text { (Weight of initial drug-Weight of free drug) }}{\text { Weight of initial drug }} \times 100$

$\%$ Drug loading $=\frac{\text { Amount of entrapped drug in SLNs }}{\text { Total weight of SLNs }} \times 100$

\section{In vitro dissolution studies}

The in vitro release of different SLN dispersions of azithromycin was carried out using a USP type II apparatus (paddle type). Formulation equivalent to $250 \mathrm{mg}$ of drug was taken in the dissolution chamber containing $900 \mathrm{~mL}$ of phosphate buffer $\mathrm{pH}$ 6.0. The temperature of the dissolution chamber was maintained at $37 \pm 0.5^{\circ} \mathrm{C}$, samples were withdrawn at predetermined intervals for $45 \mathrm{~min}$, and the same were replenished with fresh buffer to maintain the sink condition. The drug content of each sample was determined spectrophotometrically at $482 \mathrm{~nm}$ after suitable dilution with phosphate buffer pH 6.0 using $13.5 \mathrm{~mol} / \mathrm{L}$ sulfuric acid as color developing agent. The amount of drug released from the nanoparticles was calculated. ${ }^{15}$

\section{Particle size analysis}

The mean particle size and polydispersity index (PDI) were determined by dynamic light scattering (Zetasizer nano ZS, Malvern Instruments, UK). Samples after appropriate dilutions in Milli $Q$ water were taken for analysis. ${ }^{16}$ Particle size analysis for the formulations was carried out following proper dilutions in Milli $Q$ water at $25.1^{\circ} \mathrm{C}$ with equilibration time $70 \mathrm{~s}$ in triplicate.

\section{Zeta potential analysis}

Electrophoretic light scattering was used to achieve the electrophoretic mobility of nanoparticles using a Zetasizer nano ZS (Malvern Instruments, UK). Measurements were carried out in triplicate at $25.1^{\circ} \mathrm{C}$ using water as a dispersant (refractive index: 1.330) in a clear disposable zeta cell.

\section{Scanning electron microscopy}

To study the surface morphology scanning electron microscopy was used. ${ }^{17}$ The study was carried out at low accelerating voltage of about $15 \mathrm{kV}$ with load current about $80 \mathrm{~mA}$ and working distance $W D=9.1 \mathrm{~mm}$ using a standard error mean (SEM) (Model JSM 840 A, Jeol, Japan).

\section{Fourier transform infrared spectroscopy}

The compatibility study of AZT, stearic acid, and the other surfactants was performed by attenuated total reflection (ATR) at ambient temperature using a Bruker Model Alpha E (USA) through direct sampling. The microfine powered drug was sprinkled on the ATR crystal. This facilitated the refraction. The fourier transform infrared spectroscopy (FTIR) spectra of the physical mixture of drug and excipients thus obtained ascertained the compatibility of the drug with the excipients. ${ }^{18}$

\section{Stability studies}

The nanoparticles of AZT were stored in capped glass vials at $40 \pm 2^{\circ} \mathrm{C} / 75 \% \mathrm{RH} \pm 5 \% \mathrm{RH}$ for 90 days. Samples were evaluated periodically for particle size, drug content, and \% release at the end of 30,60 , and 90 days. ${ }^{14}$

\section{Differential scanning calorimetric study}

The differential scanning calorimetric (DSC) thermograms of pure drug, stearic acid, blank formulation, and AZT loaded SLNs were recorded using a Mettler-Toledo differential scanning calorimeter (Mumbai, India). A suitable quantity of sample was weighed and heated in a closed pierced aluminum pan at a scanning rate of $10^{\circ} \mathrm{C} / \mathrm{min}$ between 30 and $200^{\circ} \mathrm{C}$ and with 20 $\mathrm{mL} / \mathrm{min}$ nitrogen flow.

\section{RESULTS AND DISCUSSION}

\section{Drug content}

The drug content of nanoparticles of AZT was in the range of $88.03 \%$ to $97.86 \%$. The high shear homogenization method for preparing SLNs of azithromycin with varied proportion of stearic acid and different surfactants at different concentrations was found to be effective. The results are summarized in Table 2.

\section{Entrapment efficiency and drug loading}

To achieve high entrapment of drug in the different concentration of lipid matrix of stearic acid, the type and

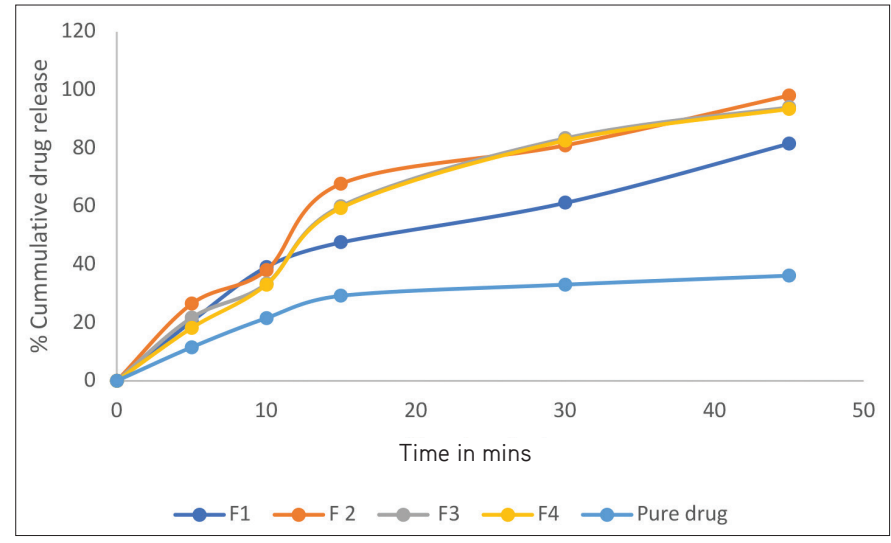

Figure 1. In vitro drug release profile (pure drug, F1 to F4)

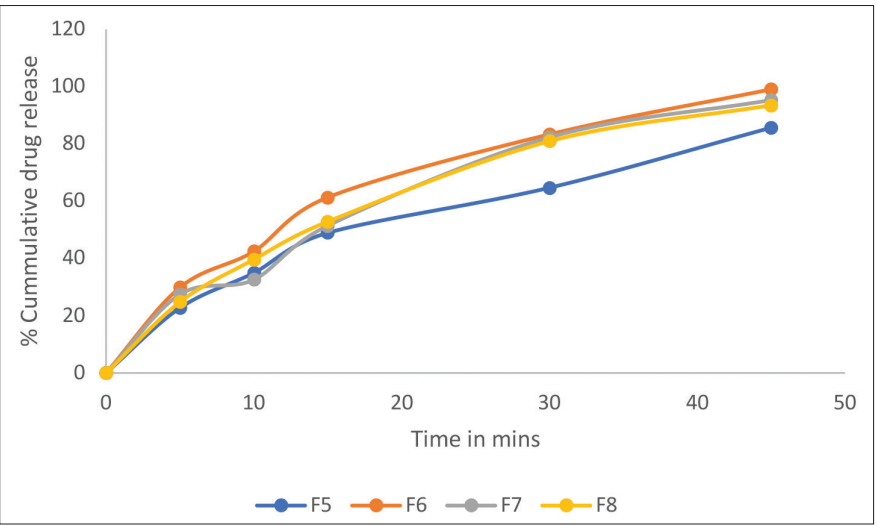

Figure 2. In vitro drug release profile (F5 to F8) 
concentration of surfactants were varied in the ratio from 1:1 to $2: 1$. It was observed that as the drug was moderately lipophilic the entrapment efficiency of the drug in the matrix was highly satisfactory. The range of the percentage entrapment and drug loading was in the range from $69 \%$ to $89 \%$ and $23 \%$ to $30 \%$, respectively, and is summarized in Table 2.

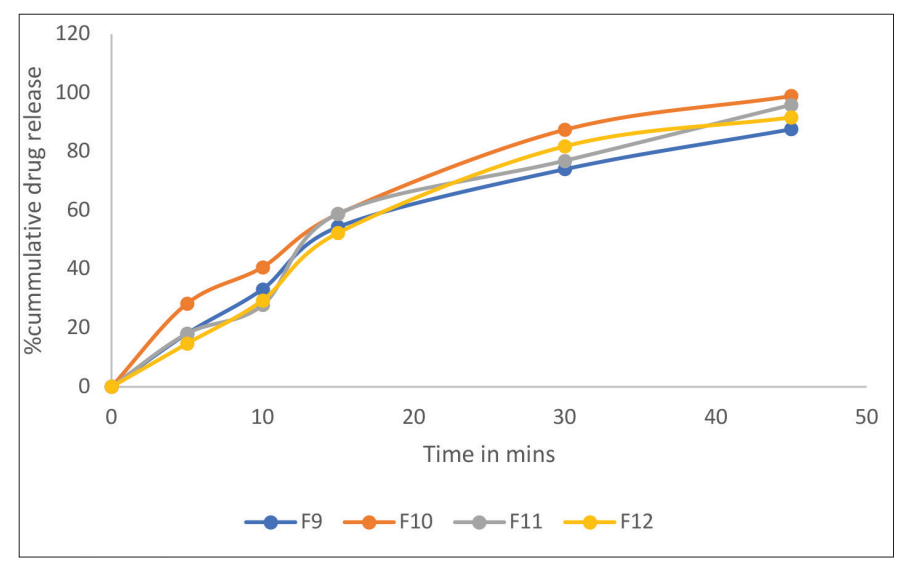

Figure 3. In vitro drug release profile (F9 to F12)

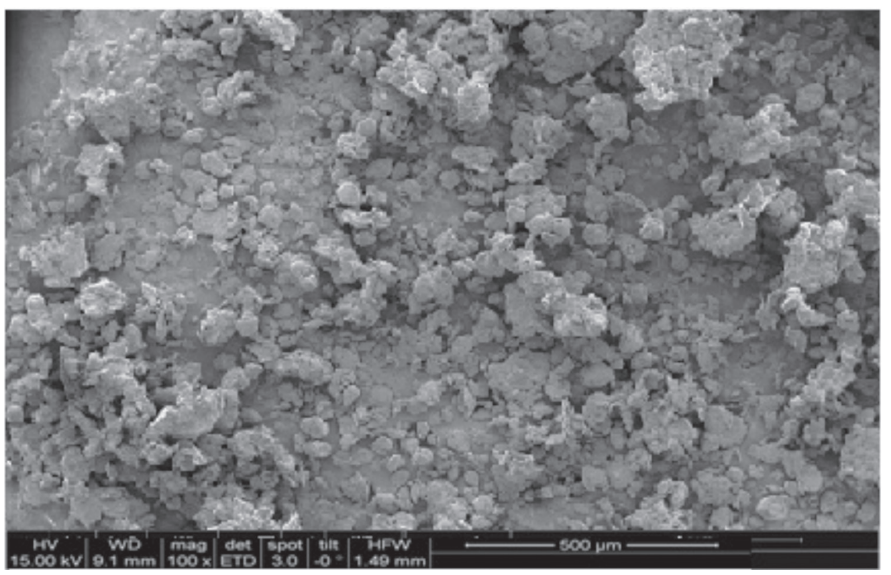

Figure 4. SEM of F2 formulation

SEM: Scanning electron microscopy

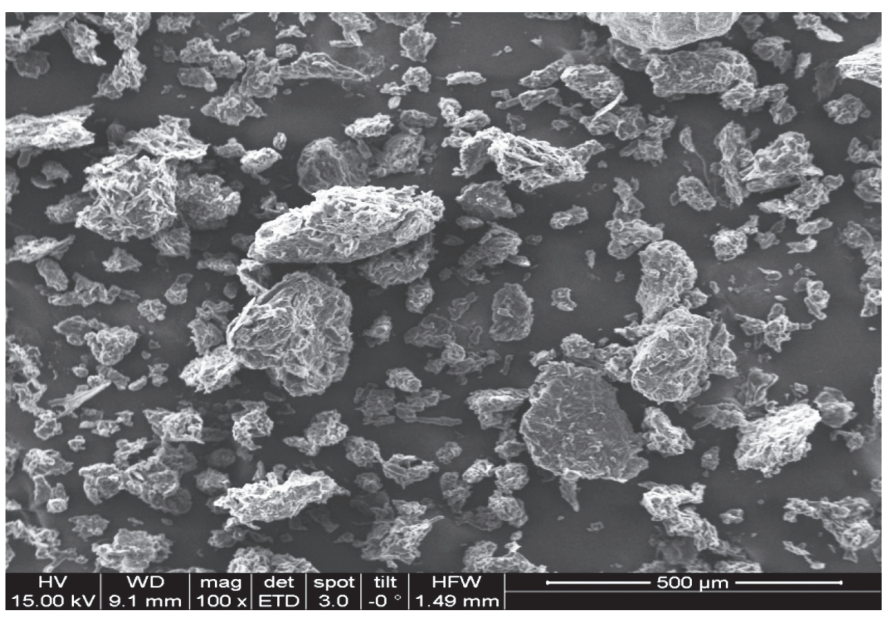

Figure 5. SEM of F6 formulation

SEM: Standard error mean

\section{Cumulative drug release}

In vitro release of the AZT loaded nanoparticles in phosphate buffer $\mathrm{pH} 6$ was studied in a USP type II dissolution apparatus over $45 \mathrm{~min}$. Data from the percentage release of drug from the SLNs are illustrated in Figures 1, 2, and 3. Formulations (F1, F5, F9, F4, F8, and F12) containing high lipid surfactant ratios showed less drug release within $45 \mathrm{~min}$. This may be attributed to the hydrophobicity of the matrix and affinity of the drug to the lipid component. Formulations containing relatively high amounts of surfactant (F3, F7, and F11) showed improved dissolution probably due to a reduction in interfacial tension with the increase in surfactant concentration. Better release was obtained from formulations with 1:1 ratio of lipid and surfactant. Formulations F2, F6, and F10 showed better release than any other formulations. This may be attributed to the effect of the concentration of surfactant on the physical properties of the nanoparticles. Poloxamer 188 was the best probably due to its low molecular weight and thereby low viscosity and high HLB compared to other surfactants, which enhanced the release of drug from the lipid matrix.19,20

\section{Table 2. Drug content, entrapment efficiency, and drug loading of AZT-SLN dispersions}

\begin{tabular}{llllll}
$\begin{array}{l}\text { Sl. } \\
\text { no. }\end{array}$ & $\begin{array}{l}\text { Formulation } \\
\text { code }\end{array}$ & $\begin{array}{l}\text { Drug } \\
\text { content (\%) } \\
\pm \text { SD }\end{array}$ & $\begin{array}{l}\text { Entrapment } \\
\text { efficiency } \\
(\%) \pm \text { SD }\end{array}$ & $\begin{array}{l}\text { Drug } \\
\text { loading (\%) } \\
\pm \text { SD }\end{array}$ & $\begin{array}{l}\% \text { Drug } \\
\text { release at 45 } \\
\text { min } \pm \text { SD }\end{array}$ \\
\hline 1 & F1 & $90.59 \pm 0.03$ & $69.38 \pm 1.78$ & $24.7 \pm 0.57$ & $81.54 \pm 0.22$ \\
\hline 2 & F2 & $93.16 \pm 0.02$ & $88.5 \pm 1.56$ & $29.9 \pm 0.98$ & $98.10 \pm 0.38$ \\
\hline 3 & F3 & $92.93 \pm 0.02$ & $79.57 \pm 2.53$ & $23.07 \pm 1.26$ & $94.03 \pm 0.64$ \\
\hline 4 & F4 & $93.16 \pm 0.04$ & $85.97 \pm 2.23$ & $29 \pm 0.78$ & $93.45 \pm 0.43$ \\
\hline 5 & F5 & $88.03 \pm 0.02$ & $71.53 \pm 2.89$ & $24.78 \pm 0.63$ & $85.66 \pm 0.13$ \\
\hline 6 & F6 & $97.86 \pm 0.04$ & $89.79 \pm 1.56$ & $30.08 \pm 1.98$ & $99.06 \pm 0.36$ \\
\hline 7 & F7 & $89.74 \pm 0.02$ & $72 \pm 0.89$ & $25.2 \pm 2.36$ & $95.31 \pm 0.19$ \\
\hline 8 & F8 & $93.16 \pm 0.03$ & $86.3 \pm 2.67$ & $25.2 \pm 0.94$ & $93.50 \pm 0.19$ \\
\hline 9 & F9 & $96.5 \pm 0.03$ & $71.82 \pm 3.25$ & $25.64 \pm 0.81$ & $87.61 \pm 0.28$ \\
\hline 10 & F10 & $97 \pm 0.03$ & $83.84 \pm 1.86$ & $29.9 \pm 1.94$ & $98.90 \pm 0.45$ \\
\hline 11 & F11 & $94.01 \pm 0.02$ & $81 \pm 2.31$ & $26.4 \pm 0.63$ & $95.93 \pm 0.36$ \\
\hline 12 & F12 & $94.27 \pm 0.03$ & $82.31 \pm 2.78$ & $23.93 \pm 2.13$ & $91.65 \pm 0.47$ \\
\hline
\end{tabular}

*All results are measured in triplicate, AZT: Azithromycin dihydrate, SLN: Solid lipid nanoparticles, SD: Standard deviation

Table 3. Particle size and zeta potential of AZT-SLN dispersion

\begin{tabular}{llll} 
Formulation code & $\begin{array}{l}\text { Particle size } \\
(\mathrm{nm}) \pm \mathrm{SD}\end{array}$ & $\begin{array}{l}\text { Zeta potential } \\
(\mathrm{mV}) \pm \mathrm{SD}\end{array}$ & $\begin{array}{l}\text { Polydispersity } \\
\text { index }\end{array}$ \\
\hline F2 & $143.1 \pm 3.91$ & $-30.1 \pm 0.35$ & 0.24 \\
\hline F6 & $144.7 \pm 2.72$ & $-31.8 \pm 1.10$ & 0.20 \\
\hline F10 & $167.2 \pm 2.70$ & $-30.6 \pm 0.26$ & 0.25 \\
\hline
\end{tabular}

*All the results are taken in triplicate, AZT: Azithromycin dihydrate, SLN: Solid lipid nanoparticles, SD: Standard deviation 


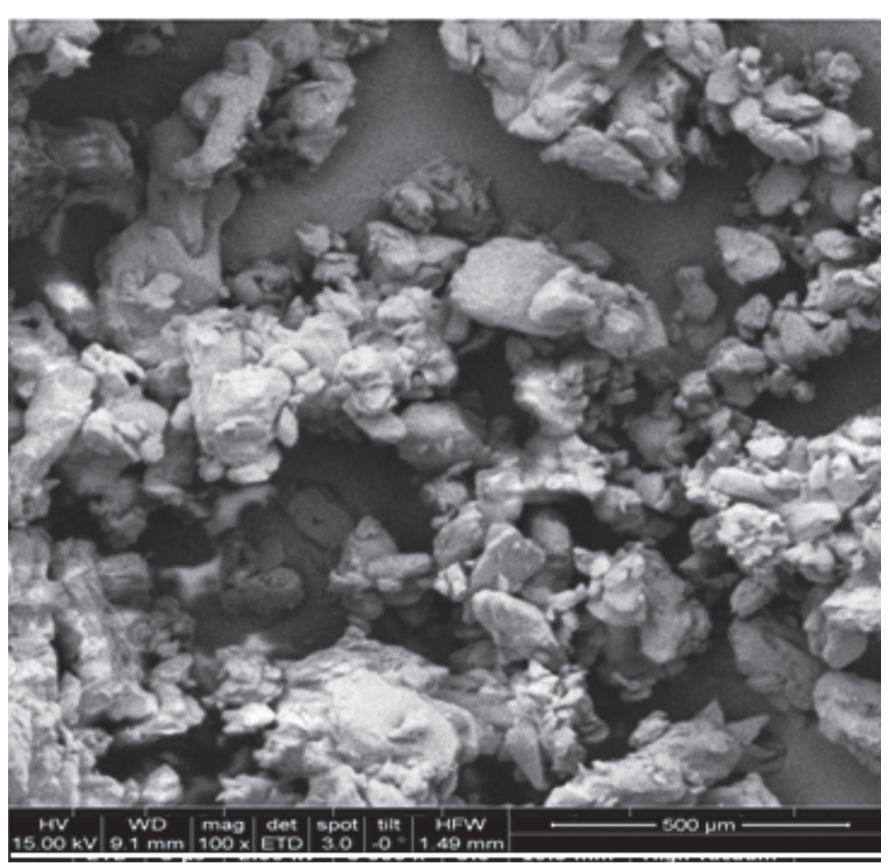

Figure 6. SEM of F10 formulation

SEM: Standard error mean

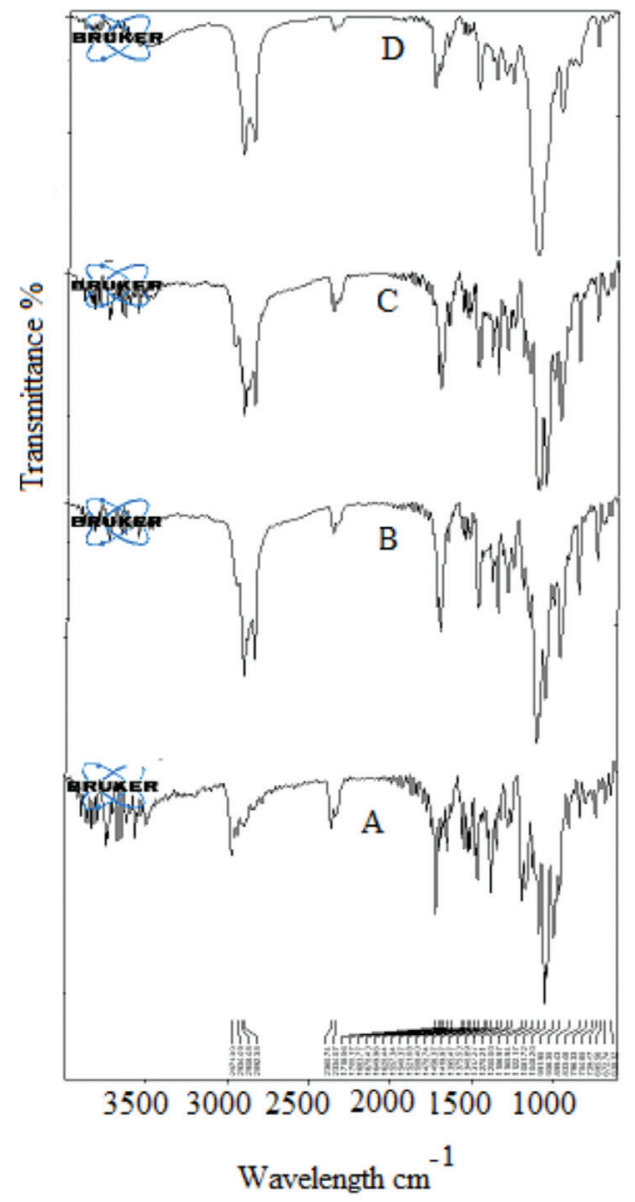

Figure 7. FTIR spectra of pure azithromycin dihydrate (a), physical mixture of drug with stearic acid and poloxamer 188 (b), drug with stearic acid and poloxamer 407 (c), drug with stearic acid and Tween 20 (d)

FTIR: Fourier transform infrared spectroscopy

\section{Particle size, PDI, and zeta potential measurement}

AZT loaded SLNs that showed the highest entrapment efficiency and drug release were subjected to further characterization of particle size, zeta potential, and PDI as shown in Table 3. The selected formulations showed a mean particle size between 143 and $167 \mathrm{~nm}$. The particles were in an acceptable nanometer range, favored for lymphatic uptake. A PDI less than 1 indicated that the formulations were monodisperse in the system. Estimation of zeta potential helps in determining surface charge and potential stability of the dispersed system. Usually high positive or negative zeta potential is required for SLNs as the same charge results in electrostatic repulsion and thereby avoids aggregation of particles. The zeta potential of the selected formulations F2, F6, and F10 was $-30.1 \mathrm{mV},-31.8$ $\mathrm{mV}$, and $-30.6 \mathrm{mV}$, respectively.

\section{Scanning electron microscopy}

The surface morphology of the SLNs was studied by SEM. Formulations F2, F6, and F10 were subjected to size and morphology studies. The photographs (Figures 4, 5, and 6) revealed that all particles were discrete entities, slightly spherical with a smooth surface. Thus the employed method of preparation of SLNs by hot homogenization was found to be appropriate for formulation of nanoparticles.

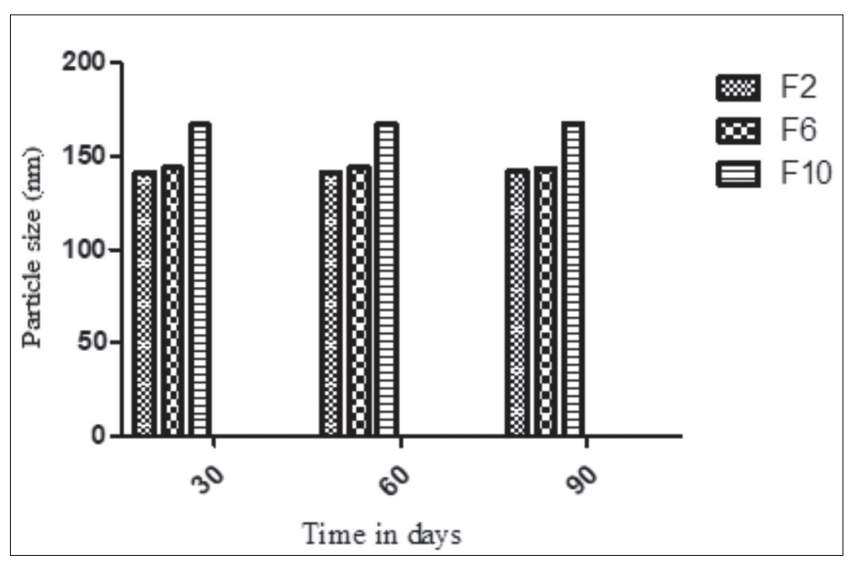

Figure 8. Stability study data of formulations F2, F6, and F10 on particle size

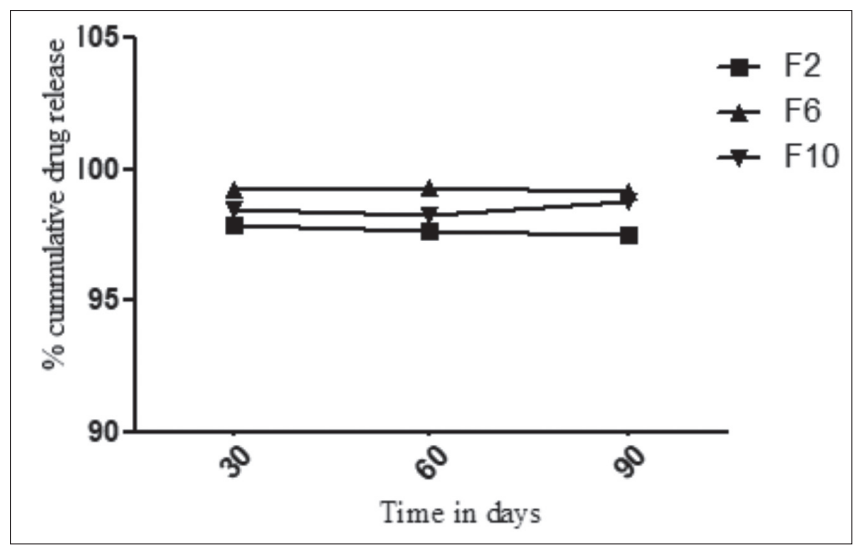

Figure 9. Stability study data of formulations F2, F6, and F10 on drug release 


\section{FTIR studies}

The FTIR spectrum of pure AZT showed the characteristic peaks at $2971.30 \mathrm{~cm}^{-1}$ (C-H stretching), $1718.56 \mathrm{~cm}^{-1} \quad(\mathrm{C}=\mathrm{O}$ ketone), $1375.53 \mathrm{~cm}^{-1}$ (C-H deformation in alkane), and 1186.97 $\mathrm{cm}^{-1}$ (C-O-C ether stretching).

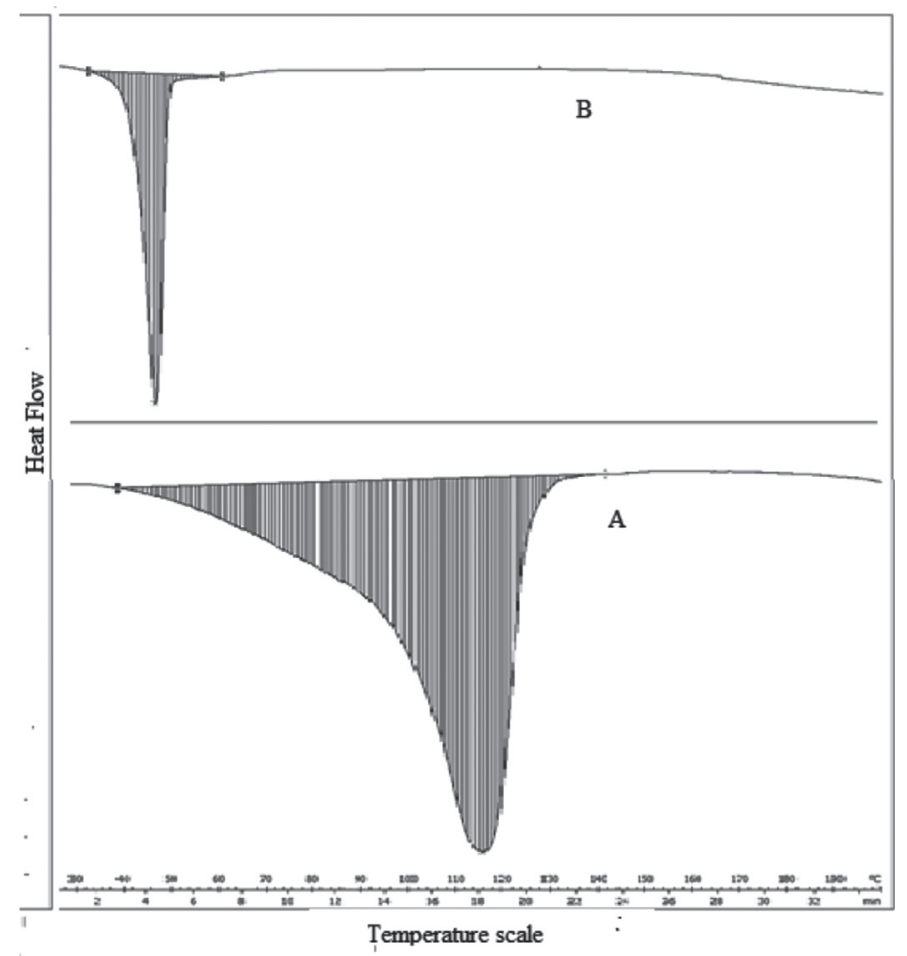

Figure 10. DSC thermogram of pure azithromycin dihydrate (a) and formulation F6 (b)

DSC: Differential scanning calorimetry

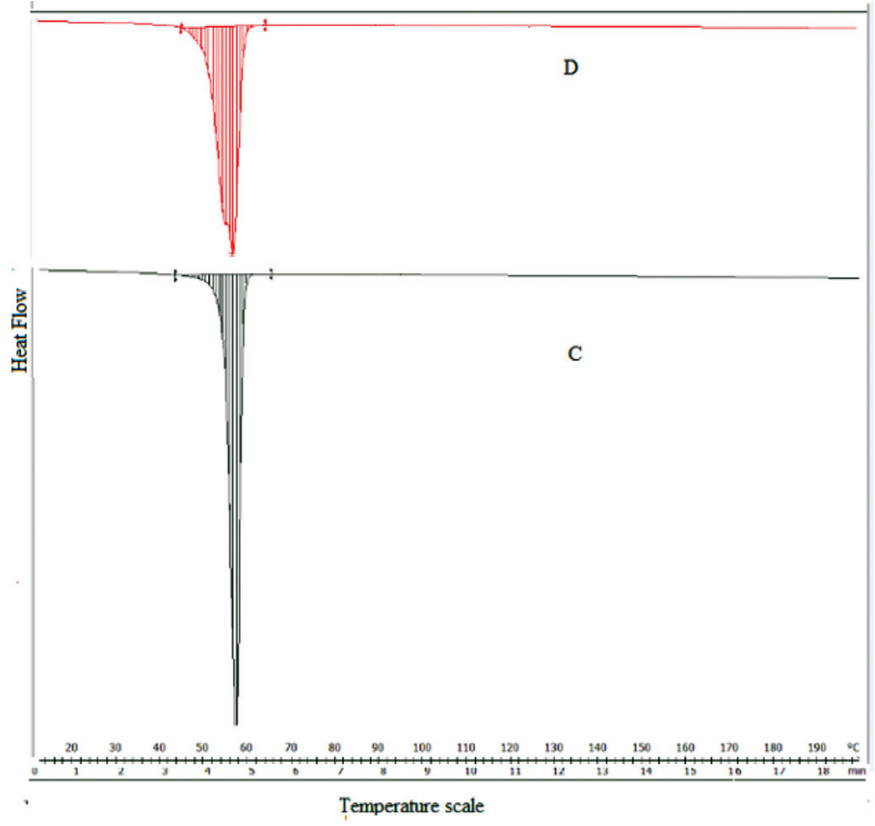

Figure 11. DSC thermogram of stearic acid (c) and blank formulation F6 (d) DSC: Differential scanning calorimetry
The FTIR spectra of the 1:1 physical mixtures of drug, stearic acid, and surfactants had all the characteristic peaks (Figure 7) and the band values of AZT confirming that all the functional groups were well preserved.

This study clearly indicated the absence of any chemical interaction between the drug and the excipients, and they were compatible with each other.

\section{Stability studies}

The selected formulations were subjected to short-term stability studies for 90 days at $40 \pm 2^{\circ} \mathrm{C} / 75 \% \pm 5 \% \mathrm{RH}$. Both physical and chemical changes were observed during the study at an interval of 30 days. Physical stability was analyzed in terms of particle size, whereas chemical stability was analyzed by the determination of drug content and change in the release profile. The drug content was found to be $93.21 \%, 97.53 \%$, and $97.11 \%$ for formulations F2, F6, and F10, respectively, at the end of the study. Figures 8 and 9 reveal that all the formulations retained their size and release profile during the study period. Therefore, the formulations were found to be stable at $40 \pm 2^{\circ} \mathrm{C} / 75 \% \pm 5 \%$ $\mathrm{RH}$.

\section{DSC studies}

DSC was used to investigate the thermal behavior of the pure drug in the lipid surfactant mixture. AZT showed an endothermic peak at $115.77^{\circ} \mathrm{C}$ with onset at $93.11^{\circ} \mathrm{C}$ and end set at $125.54^{\circ} \mathrm{C}$ corresponding to the melting point of AZT as shown in Figure 10a. It was noted that there was a shift in the melting point from $115.77^{\circ} \mathrm{C}$ to $47.07^{\circ} \mathrm{C}$ (Figure 10b), indicating that AZT must be molecularly dispersed in the formulations. ${ }^{21}$ The complete fusion of drug in the matrix was further proved by the thermograms of pure stearic acid and the blank SLN corresponds to $\mathrm{F} 6$ as shown in Figure 11.

\section{CONCLUSIONS}

This study demonstrated that AZT loaded SLNs were successfully prepared and characterized. All the formulations showed improved dissolution of AZT with satisfactory entrapment efficiency and drug loading. The characterization of formulations in terms of their particle size, zeta potential, PDI, surface morphology, and enhancement of dissolution proved the suitability of high shear homogenization to entrap AZT successfully in SLN carriers. From this study it can be concluded that poloxamer 188 is the best surfactant among the three surfactants used for improvement of solubility of AZT in the formulation of SLNs.

\section{ACKNOWLEDGEMENTS}

The authors are grateful to the management and principal of Krupanidhi College of Pharmacy, Bangalore, for providing the support and facilities to carry out the investigation. We extend our gratitude to IISC Bangalore and Aimil Limited, Bangalore, for their support. We are grateful to Dr. Reddy's Laboratories, Hyderabad, and Strides Arcolab, Bangalore, for their generous contribution of chemicals and drugs. 
Conflict of Interest: No conflict of interest was declared by the authors.

\section{REFERENCES}

1. Müller RH, Mäder K, Gohla S. Solid lipid nanoparticles (SLN) for controlled drug delivery - a review of the state of the art. Eur J Pharm Biopharm. 2000;50:161-177.

2. Ekambaram P, Sathali AAH, Priyanka K. Solid lipid nanoparticles: a review. Sci Revs Chem Commun. 2012;2:80-102.

3. Mehnert W, Mäder K. Solid lipid nanoparticles production, characterization and applications. Adv Drug Deliv Rev. 2001;47:165-196.

4. Mukherjee S, Ray S, Thakur RS. Solid lipid nanoparticles: A modern formulation approach in drug delivery system. Indian J Pharm Sci. 2009;71:349-358.

5. Yadav N, Khatak S, Sara UVS. Solid lipid nanoparticles - A review. Int J Appl Pharm. 2013;5:8-18.

6. Lode H, Borner K, Koeppe P, Schaberg T. Azithromycin--review of key chemical, pharmacokinetic and microbiological features. J Antimicrob Chemother. 1996;37:1-8.

7. Timoumi S, Mangin D, Peczalski R, Zagrouba F, Andrieu J. Stability and thermophysical properties of azithromycin dihy drate. Arabian J Chem. 2014; 7:189-195.

8. Idkaidek NM, Najib N, Salem I, Jilani J. Physiologically-based IVIVC of azithromycin. Am J Pharmacol Sci. 2014;2:100-102.

9. Amin ML. P-glycoprotein inhibition for optimal drug delivery. Drug Target Insights. 2013;7:27-34.

10. Ekambaram P, Abdul HS. Formulation and evaluation of solid lipid nanoparticles of ramipril. J Young Pharm. 2011;3:216-220.

11. Padhye SG, Nagarsenker MS. Simvastatin solid lipid nanoparticles for oral delivery: formulation development and in vivo evaluation. Indian $\mathrm{J}$ Pharm Sci. 2013;75:591-598.
12. Sultana N, Arayne MS, Hussain F, Fatima A. Degradation studies of azithromycin and its spectrophotometric determination in pharmaceutical dosage form. Pak J Pharm Sci. 2006;19:98-103.

13. El-Housiny S, Shams Eldeen MA, El-Attar YA, Salem HA, Attia D, Bendas ER, El-Nabarawi MA. Fluconazole-loaded solid lipid nanoparticles topical gel for treatment of pityriasis versicolor: formulation and clinical study. Drug Deliv. 2018;25:78-90.

14. Bhalekar M, Upadhaya P, Madgulkar A. Formulation and characterization of solid lipid nanoparticles for an anti-retroviral drug darunavir. Appl Nanosci. 2017;7:47-57.

15. Parvin S, Rafshanjani AS, Kader A. Formulation and evaluation of dexamethasone loaded stearic acid nanoparticles by high shear homogenization method. Please check the abbreviation. 2014;3:331-335.

16. Soma D, Attari Z, Reddy MS, Damodaram A, Koteshwara KBG. Solid lipid nanoparticles of irbesartan: preparation, characterization, optimization and pharmacokinetic studies. Braz J Pharm Sci. 2017;53:e15012.

17. Kommavarapu P, Maruthapillai A, Palanisamy K. Preparation, characterization and evaluation of Elvitegravir loaded solid lipid nano particles for enhanced solubility and dissolution rate. Trop J Pharm Res. 2015;14:1549-1556.

18. Singh S, Kamal SS, Sharma A, Kaur D, Katual MK, Kumar R. Formulation and in-vitro evaluation of solid lipid nanoparticles containing Levosulpiride. The Open Nanomed J. 2017;4:17-29.

19. Shi L, Li Z,Yu L, Jia H, Zheng L. Effects of Surfactants and Lipids on the Preparation of Solid Lipid Nanoparticles Using Double Emulsion Method. J Dispers Sci Technol. 2011;32:254-259.

20. Bnyan R, Khan I, Ehtezazi T, Saleem I, Gordon S, O'Neill F, Roberts M. Surfactant effects on lipid-based vesicles properties. J Pharm Sci. 2018;107:1237-1246.

21. Londhe V, Save S. Zaltoprofen loaded solid lipid nanoparticles for topical delivery: Formulation design, in vitro and ex vivo evaluation. MOJ Bioequiv Availab. 2017;4:248-254. 